\title{
Molluscs from the fossil site of "Lo Hueco" (Upper Cretaceous, Cuenca, Spain): Palaeoenvironmental and sequential implications
}

\author{
Moluscos del yacimiento paleontológico de "Lo Hueco" (Cretácico \\ Superior, Cuenca, España): Implicaciones paleoambientales y \\ secuenciales
}

P.M. Callapez ${ }^{1,2}$, F. Barroso-Barcenilla ${ }^{3,4}$, O. Cambra-Moo ${ }^{5}$, M. Segura ${ }^{4}$

\begin{abstract}
In the exceptional site of "Lo Hueco" (Cuenca, Spain) more than 8500 macroremains of plants, invertebrates and vertebrates, including titanosaur sauropod dinosaurs, have been collected in a succession of Upper Cretaceous "Garumn" facies. This work describes the molluscs found together, interpreting their palaeoenvironmental and sequential meaning. The sample is comparatively scarce due to the urgency of the excavation, and to constraints of the preservational scenario, seemingly not ideal for the fossilization of carbonated remains. Thus, the absence of well preserved shells has motivated the use of open nomenclature. Bivalves are recorded by unarticulated marly mudstone moulds of Margaritifera sp., Anodonta sp., ?Corbicula sp. and Pisidium sp., and most gastropods by gypsum moulds of Faunus sp. This association indicates a typical freshwater palaeofauna, where the presence of Melanopsidae gastropods can suggest the sporadic influence of moderately brackish-water episodes. These data confirm previous palaeoenvironmental interpretations proposed for the site. Additionally, the presence of the terrestrial gastropod Palaeocyclophorus $\mathrm{sp}$. in underlying beds with high proportion of vegetal terrestrial organic matter, and situated over an important erosive discordance, has allowed to locate the beginning of the depositional sequence of "Lo Hueco".
\end{abstract}

Key words: Mollusca, Systematics, Continental palaeoenvironments, Sequential stratigraphy, Upper Cretaceous, "Lo Hueco", Spain

\section{RESUMEN}

En el excepcional yacimiento paleontológico de "Lo Hueco" (Cuenca, España) se han obtenido más de 8500 macrorrestos de plantas, invertebrados y vertebrados, incluyendo dinosaurios saurópodos titanosaurios, en una sección del Cretácico Superior en facies "Garumn". El presente trabajo describe los moluscos recogidos, interpretando su significado paleoambiental y secuencial. La muestra obtenida resulta relativamente reducida debido a la urgencia de la excavación, y a que las condiciones diagenéticas posiblemente no han favorecido la preservación de restos carbonatados. En consecuencia, la ausencia de conchas bien preservadas ha obligado a la utilización de nomenclatura abierta. Los bivalvos identificados se encuentran representados por moldes margosos desarticulados de Margaritifera sp., Anodonta sp., ?Corbicula sp. y Pisidium sp., y la mayoría de los gasterópodos por moldes de yeso de Faunus sp. Esta asociación corresponde a una típica paleofauna de agua dulce, en la que la presencia de gasterópodos melanópsidos parece sugerir la influencia esporádica de episodios de agua salobre. Estos datos confirman las interpretaciones paleoambientales previas propuestas para el yacimiento. Adicionalmente, la presencia del gasterópodo terrestre Palaeocyclophorus sp. en niveles infrayacentes con una elevada proporción de materia orgánica vegetal, situados sobre una importante discordancia erosiva, ha permitido localizar el inicio de la secuencia deposicional correspondiente a "Lo Hueco".

Palabras clave: Mollusca, Sistemática, Paleoambientes continentales, Estratigrafía Secuencial, Cretácico Superior, "Lo Hueco", España

\footnotetext{
${ }^{1}$ Departamento de Ciências da Terra. Universidade de Coimbra. 3000-272 Coimbra, Portugal. Email: zepallac@gmail.com

${ }^{2}$ Centro de Geofísica (FCT). Universidade de Coimbra. 3000-134 Coimbra, Portugal.

${ }^{3}$ Grupo de Investigación IBERCRETA. Universidad de Alcalá de Henares. 28871 Alcalá de Henares, Spain.

${ }^{4}$ Departamento de Paleontología. Facultad de Ciencias Geológicas. Universidad Complutense de Madrid. 28040 Madrid, Spain.

${ }^{5}$ Departamento de Biología. Facultad de Ciencias. Universidad Autónoma de Madrid. 28049 Madrid, Spain.
} 

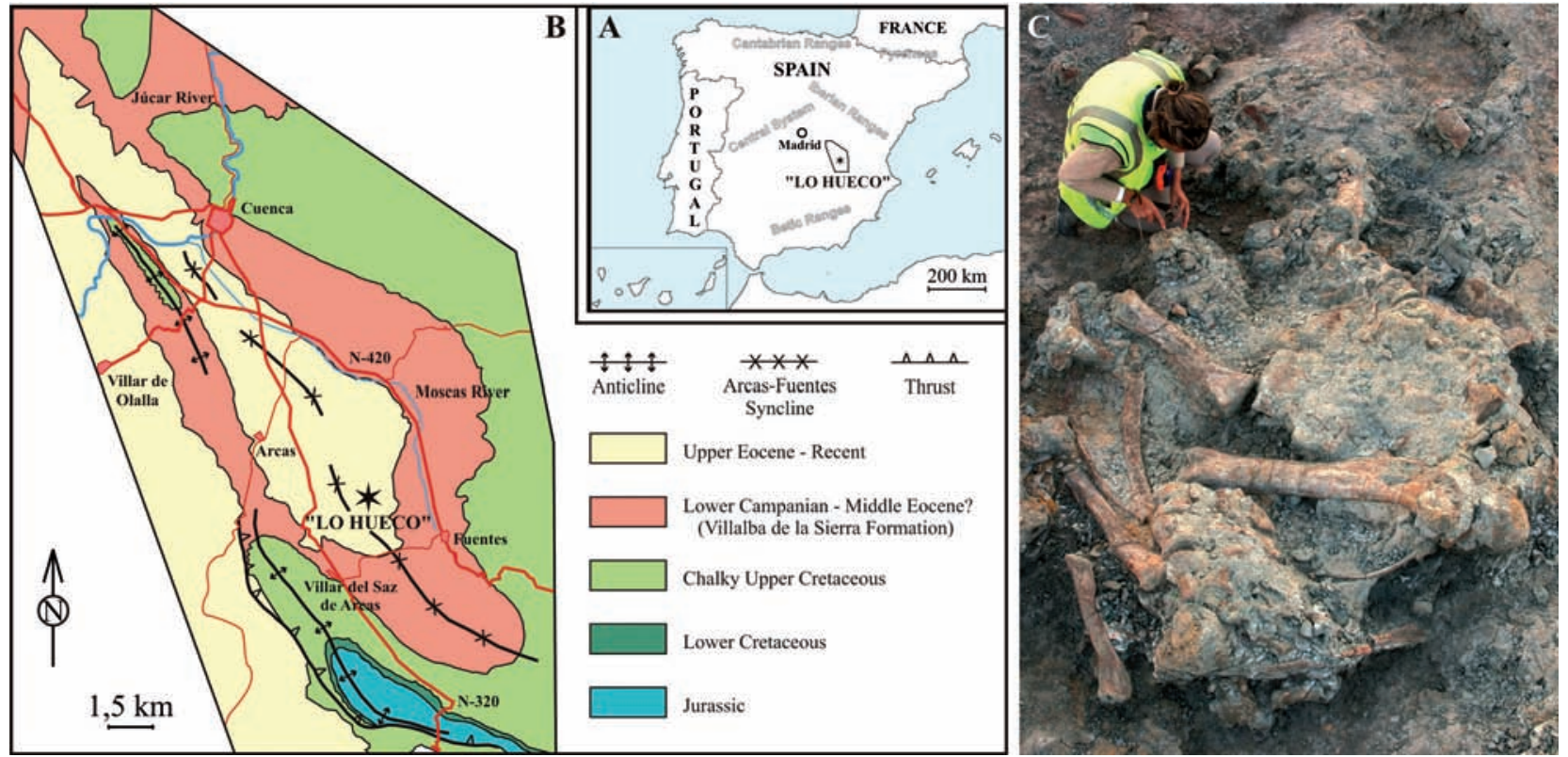

Fig. 1.-General setting and palaeontology of the fossil site of "Lo Hueco" and surrounding area. A, Geographical location. B, Detailed geological situation inside the Arcas-Fuentes Syncline. C, Bone accumulation of a titanosaur sauropod dinosaur.

\section{Introduction}

The exceptional site of "Lo Hueco" was discovered in 2007 in Cuenca, Spain, during the cutting of a little hill due to the construction of the MadridLevante highspeed railway, under Cenozoic conglomerates, in Upper Cretaceous marly mudstones (Fig. 1A-B). It includes a succession in "Garumn" facies of versicolor marly mudstone levels, partially cut by a sandy channel structure and two sulphated intervals. This site contains an extraordinary richness and diversity of fossils that constitutes a singular accumulation not only for the Spanish record but also for the whole upper Campanian-lower Maastrichtian European palaeontological record. To date, it has provided more than 8500 macroremains, mainly of vertebrates, such as actinopterygians (lepisosteids) and teleosteans fishes, amphibians, panpleurodiran (bothremydids) and pancryptodiran turtles, squamate lizards, eusuchian crocodiles, pterosaurs, and euornithopod (rhabdodontids), theropod (mainly dromaeosaurids) and sauropod (titanosaurs, some of them with nearly complete skeletons) dinosaurs, but also of plants and invertebrates (Ortega et al., 2008; Barroso-Barcenilla et al., 2009; Carenas et al., 2011; Cambra-Moo et al., 2012) (Fig. 1C). In order to a better characterization of the palaeoenvironmental and stratigraphical context of this important site, a detailed analysis of the collected sample with continental molluscs has been achieved here.

In "Lo Hueco" and surrounding area, the molluscan palaeofauna is represented by a limited number of small specimens, which have been preserved nearly all as composite and internal moulds with relicts of shell ornamentation. The scarceness of sampled molluscs results from the extreme urgency of the excavation (with the use of heavy machinery to recover the largest possible number of fossil remains and thus, the lack of methodical sieving procedure of molluscs), but can also be due to the fact that the preservational scenario was not the ideal for the fossilization of these thin and fragile carbonated remains. Both factors surely biased the real abundance and diversity values of these invertebrates in the original palaeoenvironment.

Nevertheless, the continental molluscs, including many families of land snails and freshwater bivalves and gastropods, are common guests in many Upper Cretaceous vertebrate sites, where they usually occur inside a variety of fine-grained siliciclastic rocks related with alluvial plain, lake or marsh palaeoenvironments, and can be used as useful palaeoecologic indicators when combined with other interdisciplinary data. Since the early works of Vidal (1874), Matheron (1876) and Tournouer (1879), among others, many of these molluscs have been described from the so called "Garumn" facies, an informal term 

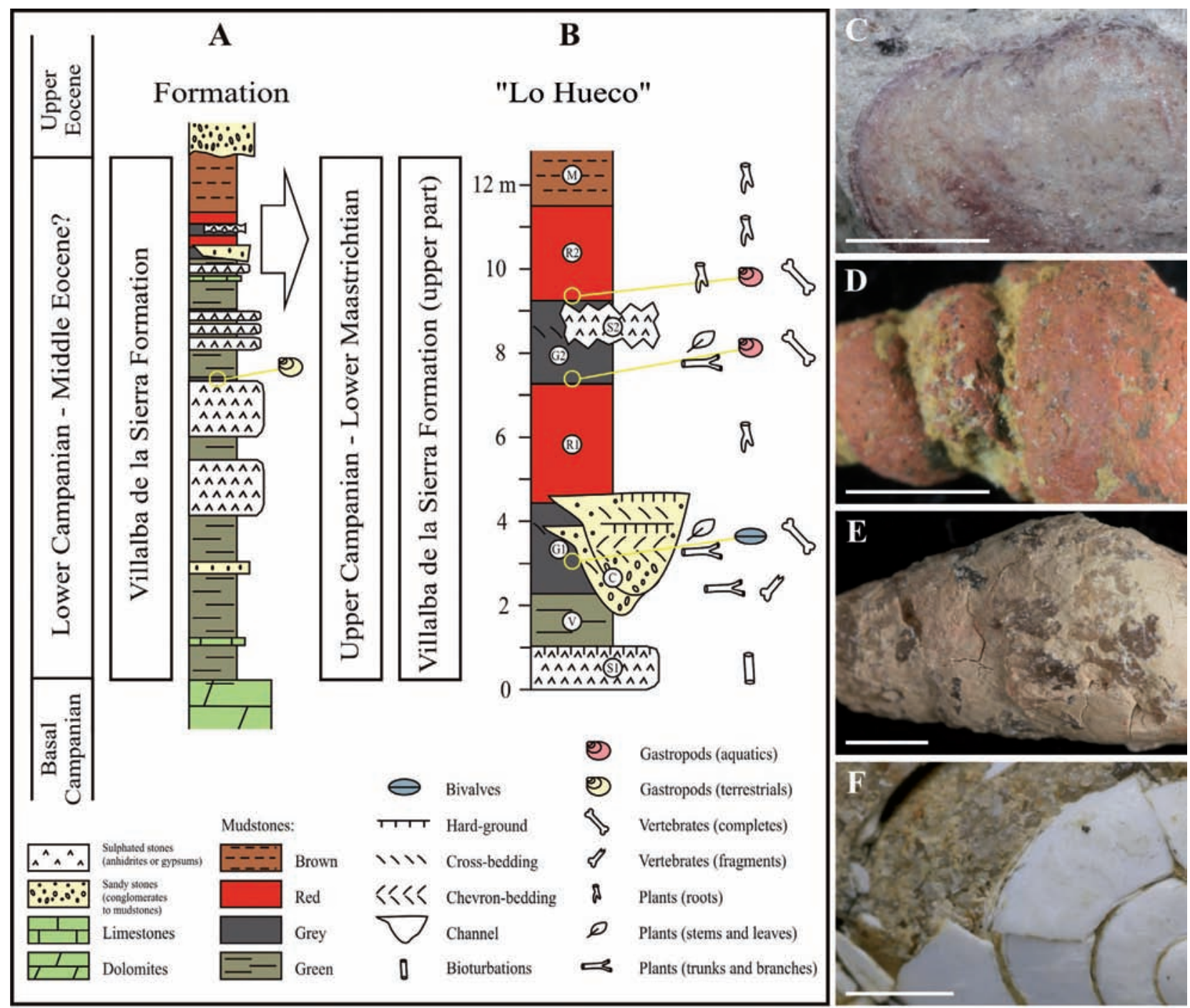

Fig. 2.-Geology of "Lo Hueco" and surrounding area, and taphonomy of their molluscs. A-B, Sections of the Villalba de la Sierra Formation (schematic, 2A), and of the site (detailed, 2B). C-F, Detailed views of a marly mudstone composite mould of bivalve from the G1 level (2C), a marly mudstone internal mould of gastropod from the base of the G2 level (2D), a gypsum composite mould of gastropod from the lower part of the R2 level (2E), and a sandy internal mould of gastropod with shell fragments from the base of the upper part of the Villalba de la Sierra Formation (2F). Scale bars are $2 \mathrm{~mm}$.

for marls, clays and gypsums, mainly of reddish coloration, deposited in shallow marine, coastal or continental environments of south-western Europe during Latest Cretaceous and Early Palaeogene. Thick series of these clayey and reddish materials have been widely recorded in the South of France (Provence and Northern Pyrenees), Centre and North of Spain (Iberian Ranges, Ebro Basin and Southern Pyrenees) and West Portugal (Beira Littoral and Estremadura), sometimes with remarkable invertebrate faunas (Oppenheim, 1895; Cotter, 1901; Repelin, 19061907; Roman, 1917; Bataller, 1949; Fabre-Taxy,
1951, 1959; Antunes \& Pais, 1978; Antunes, 1979; Antunes \& Broin, 1988; Antunes \& Russel, 1996; García et al., 2000), suggesting a long interval of continental stability on the sedimentary systems, and a significant absence of marginal relieves.

It is very interesting to note that the freshwater bivalve assemblages already known from these environments are markedly conservative, showing many taxonomic similarities with Cenozoic palaeofaunas of Western Europe. On the contrary, the terrestrial and freshwater gastropod palaeofaunas are significantly different, mixing a combination of 
Cretaceous relict families and genera, with other taxa also recorded from Paleogene deposits, and a few families with more recent ranges outside the Palearctic areas of Europe. Even though a satisfactory knowledge of the mollusc palaeofaunas of the "Garumn" facies will need further researches, which will be certainly confronted with the scarcity of well-preserved specimens, the bivalves and gastropods here presented from "Lo Hueco" can be seen as an additional case study for the resolution of this complex puzzling.

\section{Geographical and geological setting}

The "Lo Hueco" site is located in the middle east of Spain, in the centre of the province of Cuenca, close to the village of Fuentes. It is situated in the south-western branch of the Iberian Ranges, on the Arcas-Fuentes Syncline, and includes a stratigraphic interval in the "Garumn" facies belonging to the upper part of the "Margas, Arcillas y Yesos de Villalba de la Sierra" Formation (Vilas et al., 1982) (Fig. 1A-B). As detailed by Barroso-Barcenilla et al. (2009) and Carenas et al. (2011), the heterolithic and little known Villalba de la Sierra Formation has a thickness that varies widely, but in the areas where this marly, muddy and gypsiferous unit is thicker, it reaches up to $500 \mathrm{~m}$ (Vilas et al., 1982) and seems to range from the lower Campanian (Gil et al., 2004) to the middle Eocene (Ramírez-Merino, 1989). The Villalba de la Sierra Formation has been interpreted as deposited in a coastal marsh with distributary channels of terrigenous materials that suffered the sporadic establishment of sebkhas, the accumulation of clastics, mainly due to storms, and the draining of certain areas (Albert-Colomer \& Ferreiro-Padín, 1998; Lendínez-González et al., 1998) (Fig. 2A).

This lithostratigraphic unit can be divided into three intervals. The lower one consists of green marly mudstones with chalky and terrigenous canalized interbeds, probably formed in a coastal plain or marsh. The middle interval, informally defined as the "Bascuñana member" (Meléndez-Hevia, 1971), consists of massive or nodular anhydrite and gypsum beds with thin dolomitic and calcitic bioclastic interbeds. It can be related to a coastal sebkha with periodical influence of storms. The upper interval, to which belongs the stratigraphic succession of "Lo Hueco", consists of versicolor marly mudstones with chalky and sandy interbeds. It seems to correspond to a muddy coastal flood plain crossed by distributary sandy channels, exposed to brackish to fresh water aquatic influences, and with edaphic intervals (Albert-Colomer \& Ferreiro-Padín, 1998; LendínezGonzález et al., 1998; Barroso-Barcenilla et al., 2009) (Fig. 2A).

Specifically, in "Lo Hueco", a stratigraphic succession of green (V), grey (G1), red (R1), grey (G2), red (R2) and brown (M) levels of marly mudstones separated by gradual boundaries can be identified. This succession becomes partially modified in the eastern area of the outcrop by a first sulphated interval (S1) that cuts the V level by means of a net boundary, in the southern area of the outcrop by a sandy channel structure $(\mathrm{C})$ that interrupts the V, G1 and R1 levels by means of an erosive surface, and in the north-eastern area of the outcrop by a second sulphated interval (S2) that distorts at least part of the G2 level by means of a net boundary. Most of macrofossils are concentrated in only four of these lithosomes: the $\mathrm{C}$ structure, the $\mathrm{G} 1$ and $\mathrm{G} 2$ levels and the lower part of the R2 level (BarrosoBarcenilla et al., 2009; Carenas et al., 2011; Cambra-Moo et al., 2012) (Fig. 2B).

\section{Taphonomy}

Taking into account first palaeoecological approximation relating to "Lo Hueco" fossil site (Barroso-Barcenilla et al., 2009), and recently published preliminary taphonomic analysis (CambraMoo et al., in press.), herein are presented the first detailed data relating mollusc preservation. Molluscs (bivalves and gastropods) were mainly recovered from different parts of the outcrop and surrounding area during excavation phase.

Specifically, bivalves were recovered in the southern area of the outcrop from the G1 level (Fig. 2B), corresponding to the proximal part of a flooded muddy plain (close to the distributary channels). Specimens are of small size, ranging from 0.5 to 3.6 centimetres, and are preserved as composite moulds of marly mudstone partially covered with an iron oxide film formed by sedimentary infilling (sedimentary pseudomorphism sensu Fernández-López, 2000, Fig. 2C). Unfortunately, these moulds do not preserve evidences of internal structures or hinge details. No shell remains have been found within these specimens, and nearly all of them have been recovered as isolated valves, it is said, always disarticulated. These features indicate that bivalve's soft tissues were 
probably decayed before or during biostratinomic transformation (they were disarticulated before burial). After that, diagenetic alteration degraded carbonated shell until been completely disappeared. As denoted in previous works, other carbonated remains, such as charophytes, small fragments of mollusc shells and faecal pellets, also are scarce, whereas to date, ostracods have not been found in the outcrop, suggesting the disappearance of almost all carbonated fossils.

A single gastropod was obtained from screenwashing and picking of sediments for vertebrate microfossil analyses from the base of the G2 level (Fig. 2B) and is preserved as an internal mould of marly mudstone (Fig. 2D). Nevertheless, the remaining gastropods from "Lo Hueco" came out from the lower part of the R2 level (Fig. 2B), interpreted as the transition between a distal part of a flooded muddy plain (distant from the distributary channels) and the partially or totally dried part of a muddy plain. These specimens, smaller than 1 centimetre, were recovered in the northeast part of the outcrop and appear preserved as composite moulds of gypsum. Unlike what happened with bivalves, these gastropods seem not to be biostratinomic altered, and probably they were trapped in life position or after a short transport, losing their organic tissues after been finally buried. Ulterior gypsum precipitation filled the shell cavities (chemical precipitation of colloidal substances that coat the internal cavities sensu Fernández-López, 2000, Fig. 2E). As described for bivalves, no shells have been found and details of ornamentation have also been preserved as impressions on these composite moulds of gypsum.

Additional gastropods were recovered from stratigraphically underlying beds, in the base of the upper interval of the Villalba de la Sierra Formation (Fig. 2A), interpreted as a terrigenous canalized interbed with high proportion of terrestrial organic matter. These gastropods are slightly larger than the previous specimens, close to 1,5 centimetres, and are preserved as slightly crushed sandy internal moulds partially covered by shell fragments (Fig. 2F).

\section{Systematic Palaeontology}

Due to the extreme urgency of the excavation process and to the fact that the preservational scenario was not the ideal for the fossilization of car- bonated remains, the number of collected specimens is low and do not reflect the original abundance and diversity of these invertebrates in the palaeoenvironment. The sample consists of a scarce number of 15 specimens preserved with relicts of shell ornamentation. Specifically, eight disarticulated bivalves belonging to four genera and families of freshwater environments, six specimens from two fresh- or brackish-water gastropods species and a land-snail have been identified. Nowadays, these specimens are temporarily housed in Cuenca, at a storehouse rented by the Museo de las Ciencias de Castilla-La Mancha.

The systematic layout used for the taxonomic categories above the genus and family ranks was based in Moore (1969) and Bieler et al. (2010) for the bivalves, and Wenz (1938-44), Bouchet \& Rocroi (2005) and Bandel, (2006) for the gastropods. Nevertheless, the small sample and the incomplete preservation of specimens have motivated the use of open nomenclature, but is likely that some of these specimens belong to yet undescribed species, at least for the Upper Cretaceous palaeofaunas of Spain.

Phylum MOLLUSCA (Linné, 1758) Cuvier, 1795 Class BIVALVIA Linné, 1758

Superorder HETEROCONCHIA Cox, 1960 Clade PALAEOHETERODONTA Newell, 1965

Order UNIONIDA Stoliczka, 1871

Family Margaritiferidae Haas, 1940

Genus Margaritifera Schumacher, 1815

Margaritifera sp.

(Figure 3A)

Studied material: A composite mould of right-valve partly spotted by a thin film of iron oxide.

Description: Elongated valve with a rather subrectangular and compressed shape, and a slightly concave ventral margin. The posterior half side of the dorsal margin is almost straight, and shows a large ligamental area. The anterior margin is rounded. There are a significant number of concentric growth lines, closer over the ventral flanks of the valve. The umbonal area and the posterior end are incomplete. Valve length of approximately $35 \mathrm{~mm}$ and $15 \mathrm{~mm}$ of height.

Remarks: Despite the lack of the hinge area, the concave ventral margin and the overall shape of the studied specimen suggest that we are in presence of a Margaritiferidae. The genus Margaritifera is known at least since the Late Cretaceous, and has a large Palearctic and Nearctic distribution in fresh-water environments that reaches to the Iberian Peninsula (Nobre, 1941; Reis, 2006). 


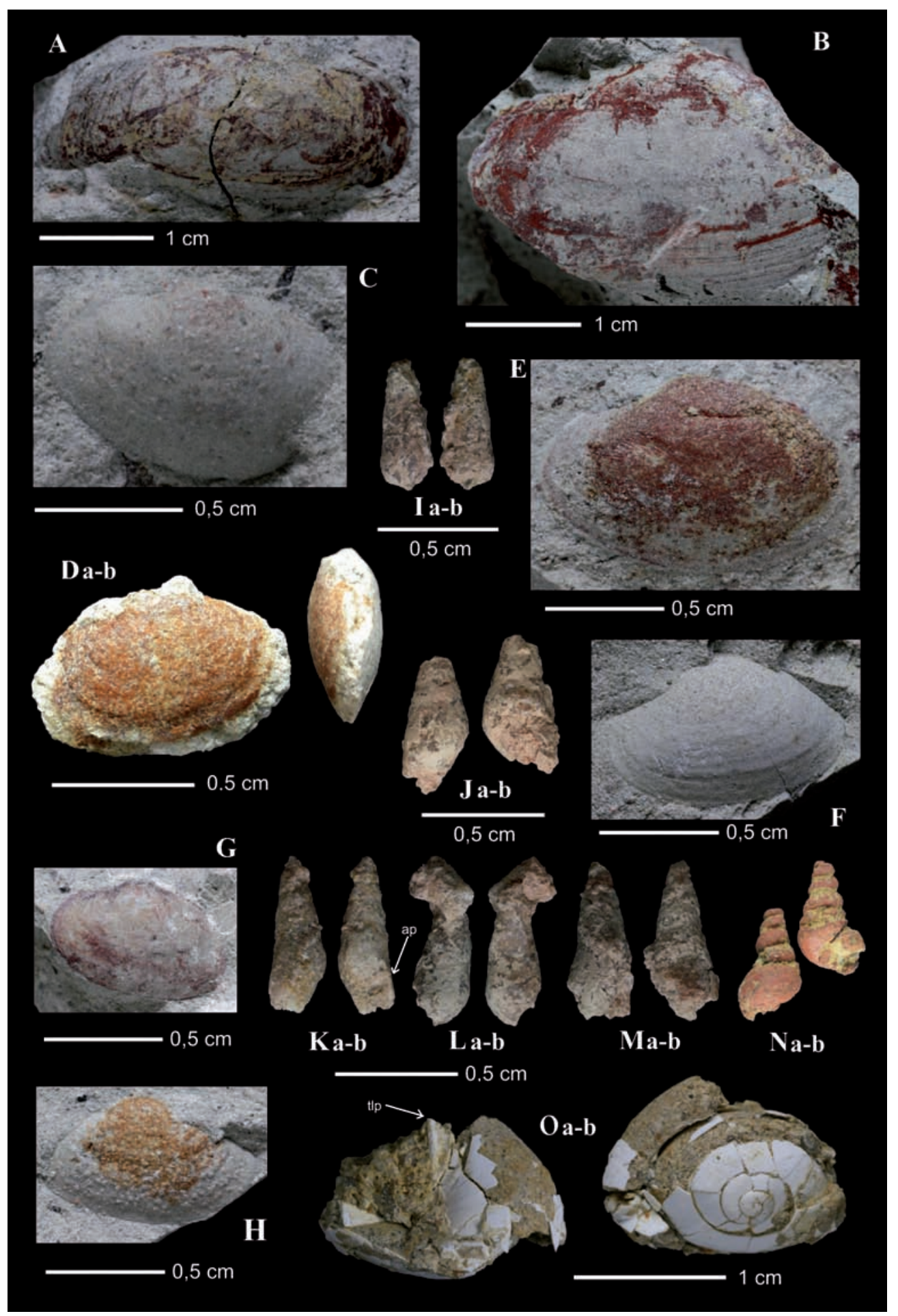

Fig. 3.-Bivalves and gastropods of "Lo Hueco" and surrounding area. A, Margaritifera sp. Composite mould of a right valve (note the slightly inflected ventral side). B-C, Anodonta sp. Composite moulds of a right valve (fragment, 3B), and of a left valve from a young specimen (3C). D, ? Corbicula sp. Composite mould of a right valve with well-impressed concentric folds: frontal (a) and lateral (b) views. E-H, Pisidium sp. Composite moulds of left valves (3E-F, H), and of a right valve (fragment, 3G). I-M, Faunus sp. A. Composite moulds of gypsum mineralization: abapertural (a) and apertural (b) views (ap - note the melanopsid like aperture in 3K). N, ?Faunus sp. B. Internal mould with reddish matrix: abapertural (a) and apertural (b) views. O, Palaeocyclophorus sp. Crushed shell and internal mould: basal (a) and upper (b) views (tlp - note the thick and slightly reflected outer lip). 
Family Unionidae Fleming, 1828

Subfamily Anodontinae Ortmann, 1910

Genus Anodonta Lamarck, 1799

Anodonta sp.

(Figure 3B-C)

Studied material: A left valve mould of a juvenile specimen (Fig. 3B) and a fragment of right valve (Fig. 3C).

Description: The smaller valve has a rounded, elliptical, slightly inflated shape and $11 \mathrm{~mm}$ of length, and $7 \mathrm{~mm}$ of height. The dorsal hinge line is moderately curve, with an acute anterior end. The surface is almost smooth with exception for several concentric growth lines. The additional fragment is an inflated composite mould of right valve, with $36 \mathrm{~mm}$ of length and well-marked growth lines.

Remarks: This unionid genus is widespread on northern Hemisphere, from the Upper Cretaceous onwards (Moore,1969). The hinge area of the studied valves is not visible, but the rounded, elliptical shape and simple ornamentation are diagnostic of Anodonta.

Clade HETERODONTA Neumayr, 1883

Order VENERIDA H. \& A. Adams, 1854

Superfamily Corbiculacea Gray, 1847

Family Corbiculidae Gray, 1847

Genus Corbicula Mühlfeld, 1811

?Corbicula sp.

(Figure 3D)

Studied material: A small mould of right-valve sampled at the lower part of the R2 level of "Lo Hueco".

Description: A slightly asymmetric, ovate mould of right valve with a well-defined ornamentation of rather strong concentric folds.

Remarks: This kind of shape and strong ornamentation are found in many fossil and recent forms of Corbiculacea, including the Lower Cretaceous to recent type genus Corbicula. However, with the hinge details unpreserved, there is no way to confirm if the typical strong and serrate lateral teeth are present. Corbicula is a cosmopolitan genus with a large and widespread fossil record. Most species inhabit in freshwater environments, but some others can support brackish conditions.

Family Pisidiidae Gray, 1857

Genus Pisidium Pfeiffer, 1821

Pisidium sp.

(Figure 3E-H)

Studied material: Three small moulds of left valve and a mould of right valve.

Description: Valve moulds are small, slightly convex, with a rounded and ovate shape, and surfaces covered by numerous, weak, concentric growth lines.

Remarks: The overall shape and ornamentation are indicative of the Pisidiidae, a widespread family of freshwater bivalves known since the Upper Cretaceous (Moore, 1969). The mould of Fig. 3H is a typical example of Pisidium, identical to several Cenozoic species of this morphologically conservative genus. The Pisidiidae is a cosmopolitan family of bivalves adapted to freshwater conditions, sometimes very restricted.

Class GASTROPODA Cuvier, 1795

Clade CAENOGASTROPODA Cox, 1960

Superfamily Cerithioidea Fleming, 1822

Family Melanopsidae H. \& A. Adams, 1854

Genus Faunus Montfort, 1810

Faunus sp. A

(Figure 3I-M)

Studied material: Five composite moulds filled with gypsum and remains of aperture and spiral ornamentation preserved.

Description: The overall shape is conical elongated, with a moderately high spire composed by 7-8 slightly rounded whorls and a shallow suture line. From specimen of Fig. 3J it can be seen that the aperture is a melanopsid like pear-shaped, narrow and angled at the top, and rounded at the base. The ornamentation is partly preserved on specimen of Fig. 3L as five regularly spaced spiral bands perceptible on the periphery of body-whorl.

Remarks: The morphologic details are close to the Melanopsidae, namely to the genus Faunus known from the Upper Cretaceous of Europe, and worldwide widespread during the Cenozoic (Wenz, 1938-44). The studied material comes from the lower part of the R2 level of "Lo Hueco". It likely belongs to a new species, but the preservation is not enough for a specific description.

\section{?Faunus sp. B}

(Figure 3N)

Studied material: A single internal mould of reddish mudstone.

Description: Internal mould of a small shell with conical shape, comprising a spire with 5-6 whorls, an expanded body whorl with a slightly marked median carina, and an aperture rounded at the base and sharply angular at the top.

Remarks: This specimen comes from the base of the G2 level of "Lo Hueco". Preservation is deficient but the overall shape and the aperture contour suggest an additional Melanopsidae species related with the previous taxon.

Superfamily Cyclophoroidea Gray, 1847

Family Cyclophoridae Gray, 1847

Genus Palaeocyclophorus Wenz, 1923

Palaeocyclophorus sp.

(Figure 30)

Studied material: Two crushed specimens with internal mould and partial shell, collected at the lower part of the studied section, equivalent to the base of the upper interval of the Villalba de la Sierra Formation. 
Description: The morphologic details show a slightly depressed globular, rather keeled species of terrestrial gastropod, with a low convex spire of 4 whorls. On the lower half of the crushed shell a considerably thick and slightly reflected outer lip is preserved, as part of a round mouth. The external ornamentation is poorly preserved, but fine growth-lines are visible. The overall diameters reach $15 \mathrm{~mm}$.

Remarks: According to Wenz (1938-44), Palaeocyclophorus is a Late Cretaceous to Eocene genus with a type species known from the Thanetian of France, P. helicinaeformis (Boissy, 1848), and mentioned in the Prodrome of d'Orbigny (Pacaud, 2007). More recently, Palaeocyclophorus has been found in several sections of vertebrate sites from the Maastrichtian of Provence, France (Kerourio, 1987; García et al., 1999; García, 2000). Most of these specimens were collected in beds with food-plain and channel belt facies, analogous to the palaeonvironments of "Lo Hueco". In the same way, the shell shape and the rounded mouth with the thick and reflected outer lip of the here studied specimens are diagnostic features of Palaeocyclophorus yet poorly known from the Iberian Upper Cretaceous continental series.

In the review of the Maastrichtian faunas of Provence, FabreTaxy (1959) also describes at least 5 species of Cyclophorus Montfort, 1810, from diverse localities. Nevertheless, these taxa should be assigned to Palaeocyclophorus or other closely related genera, since Cyclophorus is a more recent genus with a Late Cenozoic range. The same is probably true for several other examples of "Helix" or Cyclophorus cited in older works dealing with the "Garumn" facies of southwest Europe.

Bandel (2002) proposed the family Palaeocyclophoridae to group these Late Cretaceous, Paleocene and Eocene gastropods. According to Bouchet et al. (2005) this name cannot be available since there is not citation of the name of the type genus. Thus, family Cyclophoridae is here used in a broad sense.

\section{Palaeoenvironmental and sequential significance}

Most of the studied mollusc specimens from "Lo Hueco" (Fig. 4A-B) are representative of a freshwater palaeofauna dominated by unionid and heterodontid bivalves. The occurrence of some melanopsid gastropods also suggests the sporadic influence of moderately brackish-water episodes. These interpretations are consistent with an autecological analysis based on taxonomically related modern representatives. They also confirm previous interpretations of the sedimentologic, taphonomic and palaeontological data from the fossil site (Barroso-Barcenilla et al., 2009; Cambra-Moo et al., 2012).

At the same time, the single occurrence of disarticulated bivalves, some of them belonging to genera with relatively robust hinges, could be related with more energetic local events lying on the dependence of distributary channels with significant flows (and floods). Much possibly, the oligohaline to mesohaline brackish gastropod Faunus, is here interpreted as an indicator of some sporadic influence of marine conditions related with a rather close communication with the seashore and the stronger tidal streams.

A preliminary sequential analysis of the whole of the Villalba de la Sierra Formation, which has been partially or totally related to the UZA-4 second order eustatic cycle of Haq et al. (1988) by Segura et al. (2002, 2006), Gil et al. (2004) and Torres et al. (2006), among others, reveals the presence of sandy grey mudstones with terrestrial gastropods (Palaeocyclophorus) and high proportion of terrestrial organic matter of vegetal origin (Fig. 4A, C), in underlying beds to "Lo Hueco", located immediately over a marked erosive discordance. This fact has allowed to confirm the existence of an important sedimentary discontinuity that limits two major transgressive-regressive depositional sequences. The same main boundary was formed by a process of subaerial exposition and subsequent erosion ("karstification") of sulphated beds and infilling of the more depressed areas with sandy mudstones, during a main regression with strong terrestrial influence.

This sedimentary discontinuity limits a first major transgressive-regressive depositional sequence, corresponding to the lower and middle ("Bascuñana member") part of the Villalba de la Sierra Formation. It is composed mainly by green marly mudstones (lower interval) and anhydrites and gypsums (upper interval). The second major depositional sequence, coinciding to the upper part of the Villalba de la Sierra Formation, is mainly constituted by versicolor marly mudstones, and contains, among others, the materials corresponding to the "Lo Hueco" fossil site. As suggested by Meléndez-Hevia (1971) and Viallard (1973), both intervals could be divided in several minor depositional sequences with a clear regressive and shallowing tendency.

Laterally, the main part of the Villalba de la Sierra Formation seems to be related northward to the "Calizas, Arcillas y Arenas rojas de Santibáñez del Val" Formation (Floquet et al., 1982) in the Iberian Ranges, and to the "Margas de Sedano", "Calizas de Valdenoceda" (both Floquet et al., 1982) and "Sobrepeña" formations (Floquet, 1991) in the Cantabrian Ranges, and south-eastward, probably to 

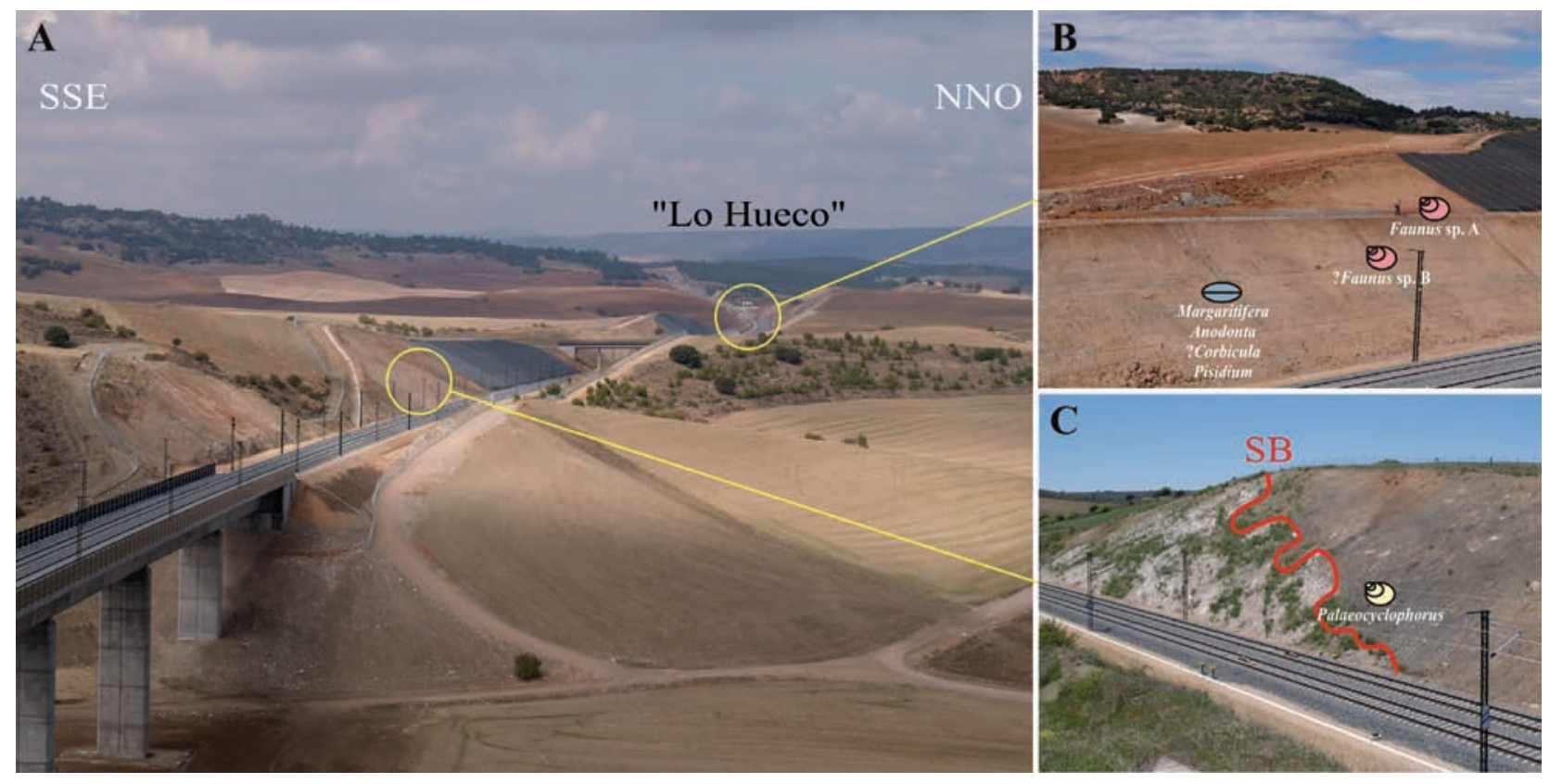

Fig. 4.- Photographic view of the Madrid-Levante highspeed railway in "Lo Hueco" and surrounding area. A. General view with the origin of the collected molluscs. B. Detailed view of "Lo Hueco", indicating the beds that have provided bivalves and aquatic gastropods. C. Detailed view of the base of the upper part of the Villalba de la Sierra Formation, with the boundary between two depositional sequences (SB), indicating the beds which have provided terrestrial gastropods.

the "Calizas y Margas de la Sierra Perenchiza" Formation (Vilas et al., 1982). Precisely, the base of Valdenoceda Formation has been described as an erosive unconformity (cycle boundary) tied to siliciclastic inputs, followed by a generally thin transgressive systems tract and by a thick highstand (regressive) systems tract (Berreteaga, 2011), and seems to coincide to the sequence boundary (seemingly of third order sensu Haq et al., 1988) identified in the here presented research (Fig. 4C).

\section{Conclusions}

It is known that molluscan associations with bivalves and gastropods are useful for integrated palaeoenvironmental reconstructions. This is true for many examples of fossil sites with remains of terrestrial vertebrates, including dinosaurs (Callapez, 2003a, 2003b), since many Meso-Cenozoic continental taxa have close modern representatives. This fact makes easier the application of palaeoecologic analysis to complete the data inferred from the vertebrate groups.

For the exceptional palaeontological site of "Lo Hueco" it has been possible to sample only a small collection of freshwater bivalves and, possibly, low brackish-water gastropods. Specifically, bivalves are recorded by marly mudstone composite moulds belonging to freshwater unionids of families Margaritiferidae (Margaritifera) and Unionidae (Anodonta), and heterodontids of families Corbiculidae (?Corbicula) and Pisidiidae (Pisidium). Gastropods are mostly known by composite moulds of gypsum corresponding to, at least, two species of Melanopsidae (Faunus) that suggest some influence of moderately brackish conditions. All bivalves have been found disarticulated, a fact that can be related with some energetic flooding episodes on the palaeoenvironment. These systematic and palaeoecologic data on molluscs from this site are in accordance with an upper Campanian-lower Maastrichtian near-coast continental muddy flood plain crossed by distributary sandy channels, exposed intermittently to brackish or marine tidal influx, freshwater flooding, and partial or total desiccation.

The presence of terrestrial gastropods (Palaeocyclophorus) in stratigraphically underlying beds with high proportion of vegetal terrestrial organic matter, over an important sedimentary discontinuity (erosive discordance), has allowed the location of the 
beginning of the depositional sequence corresponding to "Lo Hueco".

In spite of the scarceness of specimens and the lack of better conditions of preservation, these bivalves and gastropods have been studied as part of the integrated palaeontologic analysis in course for the more than 8500 fossil remains already collected, proving that molluscs can be an useful additional indicator for ecologic, palaeoenvironmental and sequential purposes.

\section{ACKNOWLEDGEMENTS}

\begin{abstract}
The authors appreciate the help provided by Dra. Angélica Torices Hernández (Universidad Complutense de Madrid, Spain) by mean of the mollusc specimens obtained from screenwashing and picking of sediments for vertebrate microfossil analyses. We also thank to Dr. Sixto Fernández López for his comments and suggestions that helped to improve this manuscript. Part of this research has been financed and carried out within projects PEII11-0237-7926 of the Junta de Castilla-La Mancha, and CGL2009-10766, CGL2009-12008, CGL201125894 and HAR-20100-23106 of the Ministerio de Ciencia e Innovación, Spain.
\end{abstract}

\section{References}

Adams, H. \& Adams, A. (1854). The Genera of Recent Mollusca (3 vols). Van Voorst Ed., London, 484 pp.

Albert-Colomer, V. \& Ferreiro-Padín, E. (1998). Explicación de la Hoja de San Lorenzo de la Parrilla, 634 (23-25). Mapa Geológico de España 1:50.000. Segunda Serie. Instituto Geológico y Minero de España, Madrid, 79 pp.

Antunes, M.T. (1979). Ensaio de síntese crítica acerca do Cretácico terminal e do Paleogénico de Portugal. Ciências da Terra, 5: 145-174.

Antunes, M.T. \& Pais, J. (1978). Notas sobre depósitos de Taveiro. Estratigrafia, Paleontologia, Idade, Paleoecologia. Ciências da Terra, 4: 109-128.

Antunes, M.T. \& Broin, F. de (1988). Le Crétacé terminal de Beira Litoral, Portugal: remarques stratigraphiques et écologiques, étude complémentaire de Rosasia soutoi (Chelonii, Bothremydidae). Ciências da Terra, 9: 153-200.

Antunes, M.T. \& Russel, D.S. (1996). Le Crétacé terminal portugais et son apport au problème de l'extinction des dinosaures. Bulletin du Muséum national d' Histoire naturelle, 4éme Série, Section C, 18: 595-606.

Bandel, K. (2002). Reevaluation and classification of Carboniferous and Permian Gastropoda belonging to the Caenogastropoda and their relation. Mitteilungen aus dem Geologisch-Paläontologischen Institut der Universität Hamburg, 86: 81-188.

Bandel, K. (2006). Families of the Cerithioidea and related superfamilies (Palaeo-Caenogastropoda; Mollusca) from the Triassic to the Recent characterized by protoconch morphology - including the description of new taxa. Freiberger Forschungshefte, C 511: 59-138.

Barroso-Barcenilla, F.; Cambra-Moo, O.; Escaso, F.; Ortega, F.; Pascual, A.; Pérez-García, A.; RodríguezLázaro, J.; Sanz, J.L.; Segura, M. \& Torices, A. (2009). New and exceptional discovery in the Upper Cretaceous of the Iberian Peninsula: the palaeontological site of "Lo Hueco", Cuenca, Spain. Cretaceous Research, 30: 1268-1278. doi:10.1016/j.cretres.2009.07.010

Bataller, J.R. (1949). Sinopsis de las especies nuevas del Cretácico de España. Anales de la Escuela de Peritos Agrícolas, 8: 5-148.

Berreteaga, A.; Floquet, M. \& Pereda-Suberbiola, X. (2011). Stratigraphy and sedimentology of vertebrate fossil-bearing sites from the Late Cretaceous series of the northern Castilian Ramp (Basque-Cantabrian Region). 28th IAS Meeting of Sedimentology abstract book, Zaragoza, Spain, 5th - 8th July 2011, p. 465.

Bieler, R.; Carter, J.G. \& Coan, E.V. (2010). Classification of bivalve families. In: Nomenclator of bivalve families (Bouchet, P.; Rocroi, J.P.; Bieler, R.; Carter, J.G. \& Coan, E.V., eds.). Malacologia, 52: 1-184.

Boissy, S.-A. de (1848). Description des coquilles fossiles du calcaire lacustre de Rilly-la-Montagne: près de Reims. Mémoires de la Société Géologique de France, 2éme Série, 3: 265-285.

Bouchet, P.; Rocroi, J.P.; Frýda, J.; Hausdorf, B.; Ponder, W.; Valdés, Á. \& Warén, A. (2005). Classification and nomenclator of gastropod families. Malacologia, 47: 1-397.

Callapez, P.M. (2003a). Notes on the Cretaceous invertebrate faunas of Portugal. 1 - A new species of Anadromus (Mollusca, Gastropoda) from the CampanianMaastrichtian of Taveiro (Coimbra, West Central Portugal). Ciências da Terra, 15: 71-76.

Callapez, P.M. (2003b). Upper Palaeocene-Early Eocene mollusks of Silveirinha (Figueira da Foz, West Central Portugal). Ciências da Terra, 15: 83-90.

Cambra-Moo, O.; Barroso-Barcenilla, F.; Berreteaga, A.; Carenas, B.; Coruña, F.; Domingo, L.; Domingo, M.S.; Elvira, A.; Escaso, F.; Ortega, F.; Pérez-García, A; Peyrot, D.; Sanz, J.L.; Segura, M.; Sopelana, A. \& Torices A. (2012). Preliminary taphonomic approach to "Lo Hueco" palaeontological site (Upper Cretaceous, Cuenca, Spain). Geobios, 46: 157-166. doi:10.1016/j.geobios.2011.04.002

Cambra-Moo, O.; Barroso-Barcenilla, F.; Coruña, F. \& Postigo-Mijarra, J.M. (2013). Exceptionally preserved vegetal remains from the Upper Cretaceous "Lo Hueco" site, Cuenca, Spain. Lethaia, 46: 127-140. doi:10.1111/j.1502-3931.2012.00331.x

Carenas, B.; Barroso-Barcenilla, F.; Berreteaga, A.; Cambra-Moo, O.; Coruña, F.; González-Acebrón, L. \& Segura, M. (2011). First overview on gypsum in the new and exceptional "Lo Hueco" fossil site (Upper Cretaceous, Cuenca, Spain). In: Gypsum: Properties, Production and Applications (Sampson, D.H., ed.). Nova Publishers, New York, 176-190. 
Cotter, J.B. (1901). Sur les mollusques terrestres de la nappe basaltique de Lisbonne. Comunicações da Direcção dos Trabalhos Geológicos de Portugal, 4: 127-146.

Cox, L.R. (1960). Thoughts on the classification of the Bivalvia. Proceedings of the Malacological Society of London, 34: 60-88.

Cuvier, G.L.C.F.D. (1795). Second Mémoire sur l'organisation et les rapports des animaux à sang blanc. Magazin Encyclopédique, ou Journal des Sciences, des Lettres et des Arts, 2: 433-449.

Fabre-Taxy, S. (1951). Faunes lagunaires et continentales du Crétacé Supérieur de Provence. 2 - Le Campanien fluvio-lacustre. Annales de Paléontologie, 37: 83-122.

Fabre-Taxy, S. (1959). Faunes lagunaires et continentales du Crétacé Supérieur de Provence. 3 - Le Maestrichtien et le Danien. Annales de Paléontologie, 45: 55-124.

Fernández-López, S.R. (2000). Temas de Tafonomía. Departamento de Paleontología, Universidad Complutense de Madrid, Madrid, $167 \mathrm{pp}$.

Fleming, J. (1822). The Philosophy of Zoology (2 vols). Constable \& Company Eds., Edinburgh, 618 pp.

Fleming, J. (1828). A history of British Animals. Bell \& Bradfute Eds., Edinburgh, 565 pp.

Floquet, M. (1991). La Plate-Forme Nord-Castillane au Crétacé supérieur (Espagne). Mémoires Géologiques de l'Université de Dijon, 14: 1-925 (2 vols.).

Floquet, M.; Alonso, A. \& Meléndez, A. (1982). El Cretácico Superior de Cameros-Castilla. In: El Cretácico de España (García, A., ed.). Universidad Complutense de Madrid, Madrid, 387-456.

García, G. (2000). Diversité des coquilles "minces" d'oeufs fossiles du Crétacé Supérieur du Sud de la France. Geobios, 33: 113-126. doi:10.1016/S00166995(00)80155-2

García, G.; Pincema, M.; Vianey-Liaud, M.; Marandat, B.; Lorenz, E.; Cheylan, G.; Cappetta, H.; Michaux, J. \& Sudre, J. (1999). Découverte du premier squelette presque complet de Rhabdodon priscus (Dinosauria, Ornithopoda) du Maastrichtien Inférieur de Provence. Comptes Rendus de l'Académie des Sciences à Paris, Sciences de la Terre et des Planètes, 328: 415-421.

García, G.; Duffaud, S.; Feist, M.; Marandat, B.; Tambareau, Y.; Villatte, J. \& Sigé, B. (2000). La Neuve, gisement à plantes, invertébrés et vertébrés du Bégudien (Sénonien Supérieur continental) du bassin d'Aixen-Provence. Geodiversitas, 22: 325-348.

Gil, J.; Carenas, B.; Segura, M.; García-Hidalgo, J.F. \& García, A. (2004). Revisión y correlación de las unidades litoestratigráficas del Cretácico Superior en la región central y oriental de España. Revista de la Sociedad Geológica de España, 17: 249-266.

Gray, J.E. (1847). A list of the genera of recent Mollus$\mathrm{ca}$, their synonyma and types. Proceedings of the Zoological Society of London, 15: 129-219.

Gray, J.E. (1857). Guide to the systematic distribution of the Mollusca in the British Museum. British Museum Trustees, London, $230 \mathrm{pp}$.
Haas, F. (1940). A tentative classification of the Palearctic Unionids. Zoological Series of Field Museum of Natural History, 24: 115-141. doi:10.5962/bhl.title.3824

Haq, B.U.; Hardenbol, J. \& Vail, P.R. (1988). Mesozoic and Cenozoic Chronostratigraphy and Eustatic Cycles. In: Sea-Level changes: An integrated approach (Wilgus, C.K.; Hastings, B.S.; Kendall, C.G.S.C.; Posamentier, H.; Ross, C.A. and Wagoner, J.C. van, eds). SEPM Special Publication, 42: 71-108.

Kerourio, P. (1987). Palaeoenvironmental reconstruction of dinosaur nesting sites based on a geochemical approach to eggshells and associated palaeosols (Maastrichtian, Provence Basin, France). Geobios, 20: 275-281. doi:10.1016/S0016-6995(87)80038-4

Lamarck, J.B. (1799). Prodrome d'une nouvelle classification des coquilles. Mémoires de la Société d'Histoire Naturelle de Paris, 1: 63-91.

Lendínez-González, A.; Muñoz del Real, J.L. \& InsuaMárquez, M. (1998). Explicación de la Hoja de Villar de Olalla, 609 (23-24). Mapa Geológico de España 1:50.000. Segunda Serie. Instituto Geológico y Minero de España, Madrid, 67 pp.

Linné, C. von. (1758). Systema Naturce. Laurentii Salvii, Holmiæ, Stockholm, 824 pp.

Matheron, P. (1876). Note sur les dépôts lacustres crétacés et d'eau saumâtre du Midi de la France. Bulletin de la Société Géologique de France, 4: 415-428.

Meléndez-Hevia, F. (1971). Estudio geológico de la Serranía de Cuenca en relación a sus posibilidades petroliferas. Tesis doctoral. Universidad Complutense de Madrid, A 153/154, 245 pp.

Montfort, P.D. de (1810). Conchyliologie Systématique (2 vols). Schoell Ed., Paris, 676 pp.

Moore, R.C. (1969). Treatise on Invertebrate Paleontology, Part N, Mollusca 6, Bivalvia (3 vols). University of Kansas Press, Boulder, 1224 pp.

Mühlfeld, M. von. (1811). Entwurf eines neuen System's der Schalthiergeh auml use. Magazin der Gesellschaft der Naturforschender Freunde zu Berlin, 5: 38-72.

Neumayr, M. (1883). Zur Morphologie des Bivalvenschlosses. Sitzungsberichte der Akademie der Wissenschaften Wien, 88: 385-419.

Newell, N.D. (1965). Classification of the Bivalvia. American Museum Novitates, 2206: 1-25.

Nobre, A. (1941). Fauna malacológica de Portugal. 2 Moluscos terrestres e fluviais. Coimbra Editora, Coimbra, $277 \mathrm{pp}$.

Oppenheim, P. (1895). Beiträge zur Binnenfauna der provençalischen Kreide. Palaeontographica, 42: 309-387.

Ortega, F.; Sanz, J.L.; Barroso-Barcenilla, F.; CambraMoo, O.; Escaso, F.; García-Oliva, M. \& Marcos-Fernandez, F. (2008). El yacimiento de macrovertebrados fósiles del Cretácico Superior de "Lo Hueco" (Fuentes, Cuenca). Palaeontologica Nova, 8: 119-131.

Ortmann, A.E. (1910). A new system of the Unionidae. Nautilus, 23: 114-120.

Pacaud, J.M. (2007). Nouveautés nomenclaturales et taxinomiques introduites par Alcide d'Orbigny dans le Prodrome $(1850,1852)$ pour les espèces du Paléocène et de l'Éocène. Geodiversitas, 29: 17-85. 
Pfeiffer, C. (1821). Naturgeschichte deutscher Land-und Süsswasser-Mollusken - 1. Landes-Industrie-Comptoir, Weimar, 135 pp.

Ramírez-Merino, J.A. (1989). Explicación de la Hoja de Las Majadas, 587 (24-23). Mapa Geológico de España 1:50.000. Segunda serie. Instituto Geológico y Minero de España, Madrid, 60 pp.

Reis, J. (2006). Atlas dos bivalves de água doce de Portugal. Instituto da Conservação da Natureza, Lisboa, 130 pp.

Repelin, J. (1906-1907). Monographie de la faune saumâtre du Campanien inferieur du sud-est de la France (zone du Plan d'Aups). Annales du Muséum d'Histoire Naturelle de Marseille, 10: 1-87.

Roman, F. (1917). Nouvelles observations sur les faunes continentales tertiaires et quaternaires de la basse vallée du Tage. Comunicações da Comissão do Serviço Geológico de Portugal, 12: 70-101.

Schumacher, C.F. (1815). Afhandling over conchyliologiske systemer, og om nogle toskallede conchylier. Oversigt over det Kongelige Danske Videnskabernes Selskabs Forhandlinger (1813-1815): 7.

Segura, M.; García, A.; Carenas, B .; García-Hidalgo, J.F. \& Gil, J. (2002). Upper Cretaceous of the Iberian Basin. In: The Geology of Spain (Gibbons, W. \& Moreno, T., eds.). The Geological Society, London, 288-292.

Segura, M.; Polo, T.; García-Hidalgo, J.F.; Gil, J.; Carenas, B. \& García, A. (2006). The Upper Cretaceous in the Tagus Basin (Central Spain): sequential analysis based on oil-well data and outcrop correlation. In: Tectonics of Western Mediterranean and North Africa (Moratti, G. \& Chalouan A., eds.). The Geological Society, London, Special Publications, 262: 231-244.
Stoliczka, F. (1871). Cretaceous fauna of southern India. The Pelecypoda, with a review of all known genera of this class, fossil and recent. Palaeontologia Indica, 6: 1-537.

Torres, T.; Ortiz, J.E. \& Arribas, I. (2006). El anticlinal y las discordancias de Pareja (Guadalajara): definición de las unidades cenozoicas de la Depresión Intermedia (provincias Cuenca y Guadalajara, España). Estudios Geológicos, 62: 89-102. doi:10.3989/egeol.066219

Tournouer, R. (1879). Description de quelques nouvelles espèces de coquilles fossiles des terrains tertiaires de l'Espagne et du Portugal. Journal de Conchyliologie, 19: $168-179$.

Viallard, P. (1973). Recherches sur le Cycle Alpin dans la Chaîne Ibérique Sud-occidentale. PhD Thesis, Université Paul Sabatier de Toulouse, 445 pp.

Vidal, L.M. (1874). Datos para el conocimiento del terreno Garumnense de Cataluña. Boletín de la Comisión del Mapa Geológico de España, 1: 209-247.

Vilas, L.; Mas, R.; García, A.; Alonso, A.; Meléndez, N. \& Rincón, R. (1982). Ibérica Suroccidental. In: El Cretácico de España (García, A., ed.). Universidad Complutense de Madrid, Madrid, 457-508.

Wenz, W. (1923-30). Gastropoda extramarina tertiaria. Fossilium Catalogus I. Animalia. 4 vols., W. Junk Ed., Berlin, 3387 pp.

Wenz, W. (1938-44). Gastropoda, Teil 1: Allgemeiner teil und Prosobranchia. Handbuch der Paläozoologie, 6. Borntraeger, Berlin, 1639 pp.

Recibido el 27 de agosto de 2012 Aceptado el 3 de abril de 2013 Publicado online el 27 de mayo de 2013 